\title{
Modeling for Estimation of Algal Bloom in Daecheong Lake Using the Satellite Imagery
}

\author{
Shincheol Back \\ Climate Change \& Agroecology Division, \\ National Academy of Agricultural Science, \\ Jeonju 560-500, South Korea
}

\author{
Jinki Park \\ Department of Rural \& Agricultural Engineering, \\ Chungbuk National University, \\ Cheongju 362-763, South Korea
}

\author{
Jonghwa Park \\ ${ }^{3}$ Department of Rural \& Agricultural Engineering, \\ Chungbuk National University, \\ Cheongju 362-763, South Korea \\ *Corresponding author
}

\begin{abstract}
Blooms of harmful algae and phycocyanin represent a significant and expanding threat to human health and aquatic resources throughout the South Korea. Algal blooms can be seen in a variety of phenomenon in nature, ranging from massive accumulations of cells that discolor the water, to dilute, inconspicuous, but highly harmful populations. Estimating the distribution and growth of algae in lake systems are particularly important for the personnel of water managements and water supply system. Algae affect the taste and smell which pose considerable filtration problems for the communities using the water system such as Daecheong Lake. Many harmful algal blooms (HABs) have significant economic impacts especially in pisciculture. We developed empirical remote sensing models to estimate Chlorophyll a (Chl.-a) concentrations and cyanobacteria synoptically, over the Daecheong lake using available Landsat TM and ETM+ data. In contrast to previous in situ studies of the cyanobacterial specific pigment such as phycocyanin, we developed remote sensing models capable of directly detecting cyanobacterial biovolume. This distinction is important because Landsat TM and ETM+ data lacks the spectral band information required for optimal phycocyanin detection. Developed model was calibrated and cross-validated with existing in situ measurements from Daecheong lake's Long-Term Water Quality Monitoring Program and Algae Alam System (AAS). Three lake station measurements taken between 2004 and 2012 were matched with radiometrically converted reflectance data from three spectral bands on the Landsat TM and ETM+ sensor. Stepwise multi-linear regression indicated data from Landsat TM and ETM+ bands 1, 2 and 4 were most significant for predicting Chl.a and cyanobacteria biovolume. Based on statistical analysis, the linear models are that included visible band ratios slightly outperformed single band models. The final models captured the extents of cyanobacterial blooms throughout the 2004-2012 study period. The results serve as an added broad area monitoring tool for water resource managers and present new insight into the initiation and propagation of cyanobacterial blooms in Daecheong lake
\end{abstract}

Keywords-algal bloom; phycocyanin; aquatic resourcese; chlorophyll a;Landsat TM and ETM+

\section{INTRODUCTION}

Algal bloom in adequate amount is beneficial for aquaculture and wild fisheries operations. However, in some situations algal blooms can have a negative effect, causing severe economic losses to aquaculture, fisheries and tourism operations and having major environmental and human health impacts [1]. Cyanobacteria, a phytoplankton that have a characteristic pigment phycocyanin, can be found in all lake and reservoir ecosystems, ranging from small ponds to lakes. Its presence and volume is important since they are the major toxic blooms producing phytoplankton group in freshwater ecosystems [2]. Such toxins can become a major problem for public health if contaminated water is stored in reservoirs, and used in irrigation, fishing, cultivation and recreational purpose[3] [4].

In present situation with rapidly changing climate, land cover and land use simultaneously with increasing anthropogenic impact on reservoirs and inland aquatic ecosystems, there is an urgent need to improve the effectiveness of algal bloom monitoring methods. The demand of a unified monitoring of inland waters has inspired the formation of Algal Alarm System (AAS), Ministry of Environment in South Korea. The main objective of AAS is to prevent the occurrence of algal bloom phenomenon in advance and protect water bodies from further degradation, which in turn requires monitoring of various biological quality elements for determining the current status of an aquatic body. It has been cautiously operating the algal alarm and danger forecast system for Daecheong Lake from 1996. AAS monitors chlorophyll $a$ concentration ( $\mathrm{Chl} a$ ), cyanobacterial biomass (CY) and phytoplankton biomass (TBM), the tree important ecological parameters that give an overview of phytoplankton state in lakes and reservoirs. The monitoring of satellite imageries and new remote sensing algorithms is an ongoing process; moreover, because of the spatial and temporal variability of algal blooms, it is becoming essential to assess whether standard monitoring and mapping methods could be supported with remote sensing techniques. 
The aim of the present study was to investigate and estimate whether spectral resolution of multispectral sensors is adequate for quantitative mapping of algal bloom and whether it is possible to separate potentially harmful blooms of cyanobacteria from waters dominated by algae using Landsat TM and ETM+ satellites.

\section{MATERIALS AND METHODS}

\section{A. Locations}

For this study, cyanobacterial data from Daecheong lake was taken for the present study. Daecheong lake has a major dam and it is slowly developing and forest area. The study area falls in the latitudinal and longitudinal extensions of $36^{\circ} 10^{\prime}$ $36^{\circ} 31^{\prime} \mathrm{N}$ and $127^{\circ} 28^{\prime}-127^{\circ} 50^{\prime} \mathrm{E}$ on the middle of South Korea. The geographic location of this lake is shown in Figure I. Table I summarizes the location and depth of observation site in Daecheong lakes.

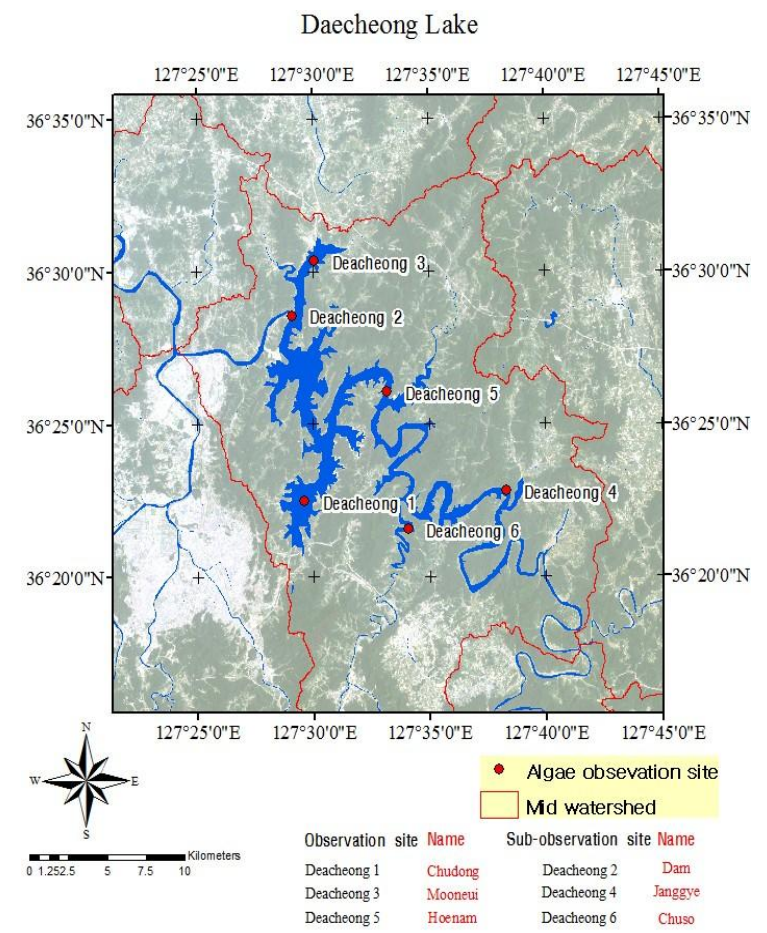

FIGURE I. OBSERVATION SITE MAP OF ALGAL BLOOM IN DAECHEONG LAKE

TABLE I. LOCATION AND DEPTH OF THE IN-SITU OBSERVATION SITE IN DAECHEONG LAKE

\begin{tabular}{|c|c|c|c|c|}
\hline Code Name & Name & $\begin{array}{l}\text { Longitude } \\
\text { (DMS) }\end{array}$ & $\begin{array}{c}\text { Latitude } \\
\text { (DMS) }\end{array}$ & $\begin{array}{c}\text { Depth } \\
\text { (m) }\end{array}$ \\
\hline Daecheong 1 & Chudong & E $127^{\circ} 29^{\prime} 37^{\prime \prime}$ & $\mathrm{N} 36^{\circ} 22^{\prime} 29^{\prime \prime}$ & $10 \sim 20$ \\
\hline Daecheong 3 & Mooneui & E $127^{\circ} 30^{\prime} 04^{\prime \prime}$ & $\mathrm{N} 36^{\circ} 30^{\prime} 22^{\prime \prime}$ & $8 \sim 18$ \\
\hline Daecheong 5 & Hoenam & $\mathrm{E} 127^{\circ} 33^{\prime} 12^{\prime \prime}$ & $\mathrm{N} 36^{\circ} 26^{\prime} 03^{\prime \prime}$ & $20 \sim 31$ \\
\hline Daecheong 2 & Dam & E $127^{\circ} 29^{\prime} 06^{\prime \prime}$ & $\mathrm{N} 36^{\circ} 28^{\prime} 34^{\prime \prime}$ & $33 \sim 44$ \\
\hline Daecheong 4 & Janggye & $\mathrm{E} 127^{\circ} 38^{\prime} 19^{\prime \prime}$ & $\mathrm{N} 36^{\circ} 22^{\prime} 49^{\prime \prime}$ & $8 \sim 16$ \\
\hline Daecheong 6 & Chuso & E $127^{\circ} 34^{\prime} 05^{\prime \prime}$ & $\mathrm{N} 36^{\circ} 21^{\prime} 33^{\prime \prime}$ & $4 \sim 16$ \\
\hline
\end{tabular}

\section{B. Data description}

The existing water quality value was used to assess the present condition of algal bloom. Water samples from each six in-situ observation site (Table I and $I$ ) were collected and tested for cynobacterial species identification and cell count. The Landsat TM and ETM+ satellite imagery was obtained from the U.S. Geological Survey's (USGS) Website for the period of June 2009 to October 2009 (Table III). For water quality, data from Gunkang Environment Agency water quality measurement network for the period of Apr. 2004 to Nov. 2012 was used.

\section{TABLE II. DURATION OF ALGAL BLOOM ALERT IN DAECHEONG LAKE}

\begin{tabular}{|c|c|c|c|c|}
\hline \multirow[b]{2}{*}{ Year } & \multirow{2}{*}{$\begin{array}{c}\text { In-situ } \\
\text { Observation }\end{array}$} & \multicolumn{2}{|c|}{ Criteria of algal bloom (day) } & \multirow{2}{*}{$\begin{array}{c}\text { Total } \\
\text { durati } \\
\text { on }\end{array}$} \\
\hline & & Caution (days) & $\begin{array}{c}\text { Warning } \\
\text { (days) }\end{array}$ & \\
\hline \multirow{3}{*}{2005} & Hoenam & $8.2 \sim 10.7(67)$ & & \multirow{3}{*}{67 day } \\
\hline & Choodong & $9.1 \sim 9.30(30)$ & & \\
\hline & Mooneui & $9.1 \sim 9.30(30)$ & & \\
\hline \multirow{3}{*}{2006} & Hoenam & $8.4 \sim 10.4(62)$ & - & \multirow{3}{*}{79 day } \\
\hline & Choodong & $8.18 \sim 10.20(64)$ & - & \\
\hline & Mooneui & $9.7 \sim 10.20(44)$ & $\begin{array}{c}8.4 \sim 8.18 \\
(15)\end{array}$ & \\
\hline \multirow{2}{*}{2007} & Hoenam & $10.6 \sim 10.19(14)$ & \multirow[b]{2}{*}{ - } & \multirow{2}{*}{14 day } \\
\hline & Choodong & $10.6 \sim 10.19(14)$ & & \\
\hline 2008 & Hoenam & $7.25 \sim 8.8(15)$ & & 15 day \\
\hline 2009 & Hoenam & $\begin{array}{l}8.6 \sim 8.20(15) \\
9.8 \sim 9.21(14)\end{array}$ & $\begin{array}{c}8.21 \sim 9.7 \\
\quad(18)\end{array}$ & 47 day \\
\hline
\end{tabular}

TABLE III. ACQUISITION DATE OF IMAGERY AND IN-SITU

\begin{tabular}{c|c|c}
\hline \multirow{2}{*}{ Sensor } & \multicolumn{2}{|c}{ Acquisition date } \\
\cline { 2 - 3 } & Imagery & In-situ \\
\hline Landsat ETM+ & Jun.18,2009 & Jun.17,2009 \\
\hline Landsat TM & Jun.26,2009 & Jun.24,2009 \\
\hline Landsat ETM+ & Aug.21,2009 & Aug.19,2009 \\
\hline Landsat ETM+ & Oct.24,2009 & Oct.21,2009
\end{tabular}

\section{Methodology}

By using Landsat TM and ETM+ satellite images and field bservation water quality data which can be used to describe the bloom condition in the six observational point, we have eveloped a multiple regression model for estimation and the servation of the algal blooming phenomenon (Figure $\amalg$ ). 


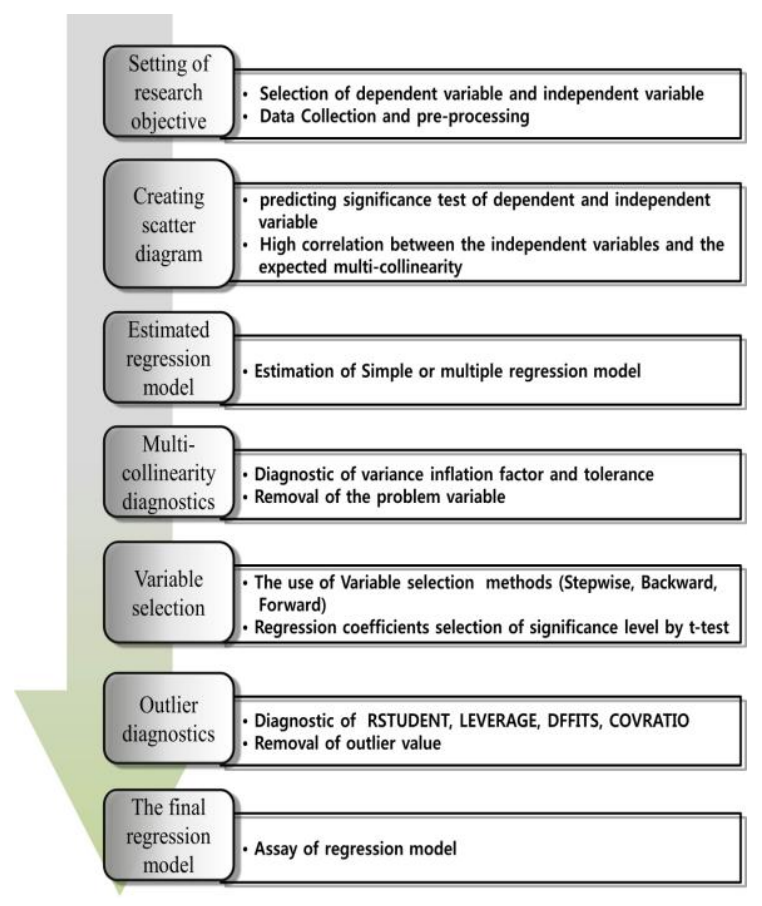

FIGURE II. FLOW CHART OF REGRESSION MODEL

A map of algal blooming phenomenon in the Daecheng lake has created by using multiple regression model. The study progress shows as Figure III.

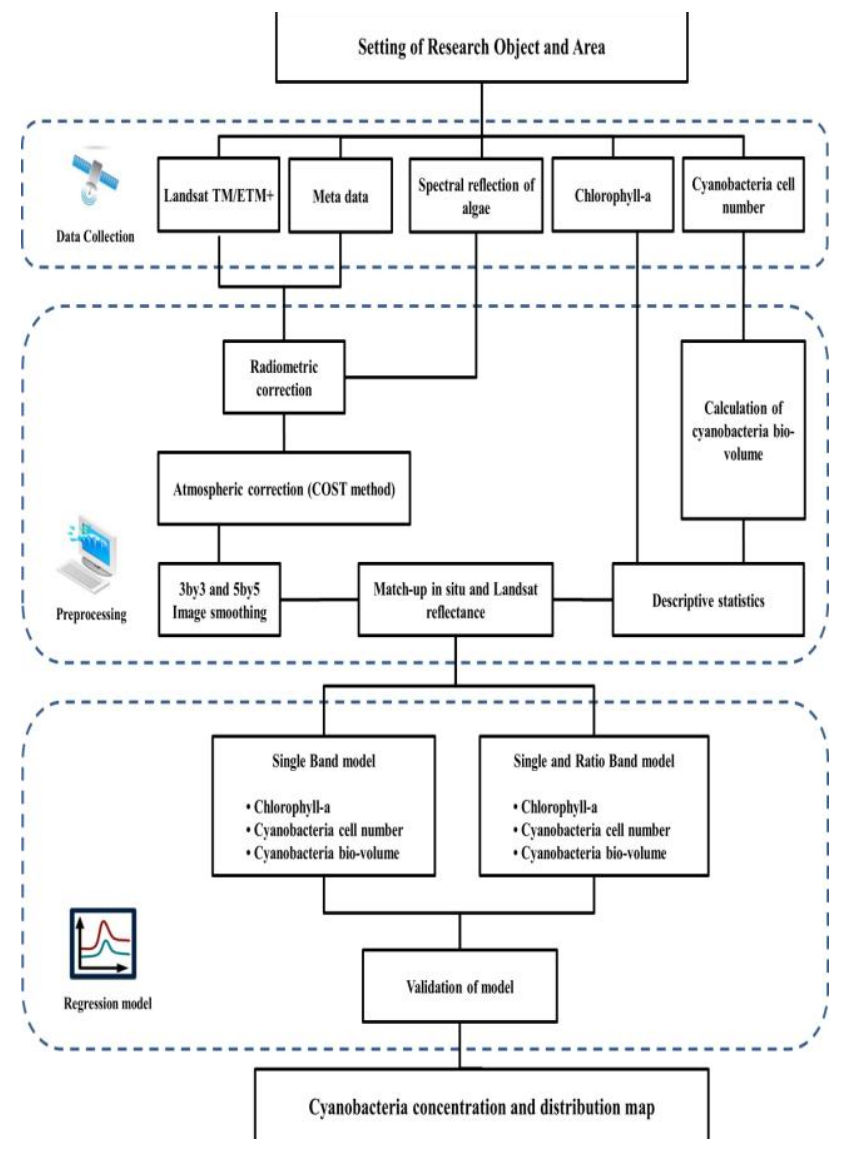

FIGURE III. FLOW CHART OF STUDY PROCESS

\section{RESULTS AND DISCUSSION}

\section{A. Distributions of Chl. - a and Cynobacteria}

Monthly distribution of Chl.-a (Figure. IV) and cyanobacteria number (Figure. V) measured during the periods of water sampling has been displayed using box plot model.

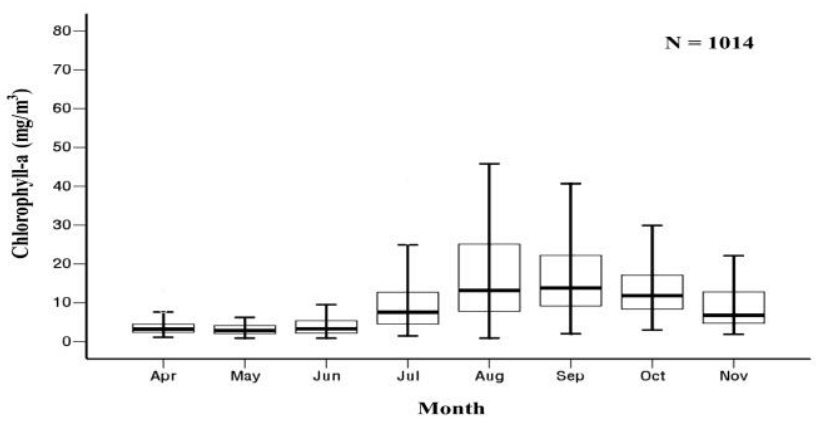

FIGURE IV MONTHLY DISTRIBUTION OF CHL-A

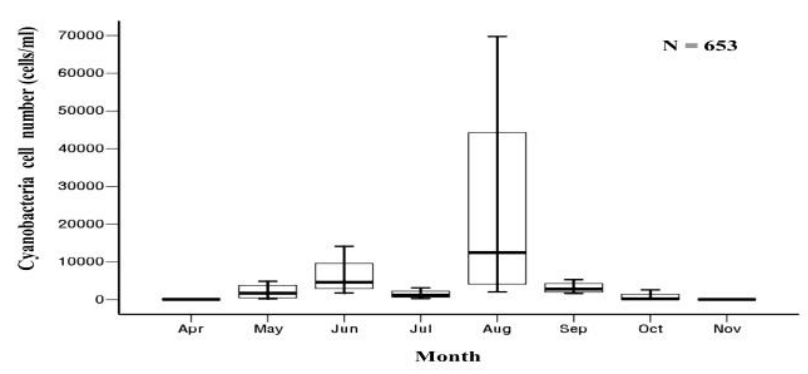

FIGURE V. MONTHLY DISTRIBUTION OF CYANOBACTERIA
NUMBER

The results demonstrate a higher concentration of Chl.-a during summer and autumns. Chl.-a increases from the end of July, peak in August and then slowly decrease as autumn progressed. The high temperature and addition of rain water in summer triggers a healthy growth in algal and water bio community. But increasing supply of rain water run-off, water nutrient level also increase and therefore, rise the possibilities of algal bloom. As shown in Figure V, the cyanobacterial number is highest in August and then in June. It was found that the seasonal distribution of cyanobacterial biovolume is a constant cycle which have a strong relationship with solar radiation and water nutrients content. Warm temperatures have a positive effect, inducing an increase in cyanobacteria biomass while cold temperatures lead to a decrease.

\section{B. Distributions of Cyanobacteria Cell Number}

The Cyanobacteria Cell Number was estimated based on the dominant species of Daechung Lake during the summer. As given in Table 4, the abundance of cyanobacteria species Anabaena is highest, next Oscillatoria, Microcystis, Aphanizomenon appeared in order. Therefore we used Cyanobacteria Cell Number as a variable in our model in attempt to estimate the possibility of separating cyanobacteria from algal species based on remote sensing reflectance. During our study period maximum Cyanobacteria Cell was recorded 20,000cells/ml in August 2009 at Hoenam. 
TABLE IV. DOMINANT SPECIES OF CYANOBACTERIA IN DAECHEONG LAKE

\begin{tabular}{l|l|l|l|c}
\hline Genus & Anabaena & Microcystis & Aphanizomenon & Oscillatioria \\
\hline Species & $\begin{array}{l}\text { Anabaena } \\
\text { spiroides } \\
\text { var. crassa }\end{array}$ & $\begin{array}{l}\text { Microcystis } \\
\text { aeruginosa }\end{array}$ & $\begin{array}{l}\text { Aphanizomenon } \\
\text { flosaquae }\end{array}$ & $\begin{array}{l}\text { Oscillatioria } \\
\text { limosa }\end{array}$ \\
\hline $\begin{array}{l}\text { Mean cell } \\
\text { volume } \\
\left(\mu \mathrm{m}^{3} / \mathrm{cell}\right)\end{array}$ & 575.2 & 58.2 & 17.6 & 166.3 \\
\hline
\end{tabular}

C. Relationships between Chl.-a and Cyanobacteria Cell Number

Figure VI shows the correlation between the Cyanobacteria Cell Number and the Chl.-a. A high coefficient 0.86 , indicate a significant relation between Chl.-a and cyanobacteria.

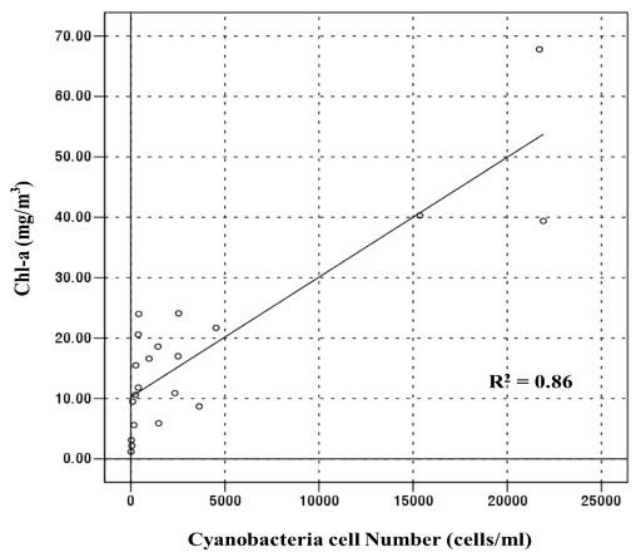

FIGURE VI. RELATIONSHIPS BETWEEN CHL.-A AND CYANOBACTERIA CELL NUMBER AT DAECHEONG LAKE

\section{Relationships between Measured and Predicted Cyanobacteria Cell Number}

Two Landsat spectral band i.e. Band $2(0.52-0.60 \mu \mathrm{m})$ and Band $4(0.77-0.90 \mu \mathrm{m})$ useful for assessing vegetation and biomass content are used for regression study. Among the several experimental models the best regression models for detecting cyanobacteria cell number is chosen for further study. The final cyanobacteria cell number models based on the band ratio is presented by the following equation:

$$
\begin{aligned}
\text { Cyano }_{N} & =381287.94(B 4)+12028.277\left(\frac{B 2}{B 4}\right) \\
& +23370.935\left(\frac{B 4}{B 2}\right)-49961.989
\end{aligned}
$$

Where, CyanoN is cyanobacteria cell number, B2 is Band 2 of Landsat, , B4 is Band 4 of Landsat.

The $\mathrm{R}^{2}$ value of the regression model is found to be 0.835 with a $\mathrm{p}$ value 0.001 . Root mean square deviation (RMSD) between observed and predicted cell number is $10.35 \%$, 2269.18cells / $\mathrm{ml}$.

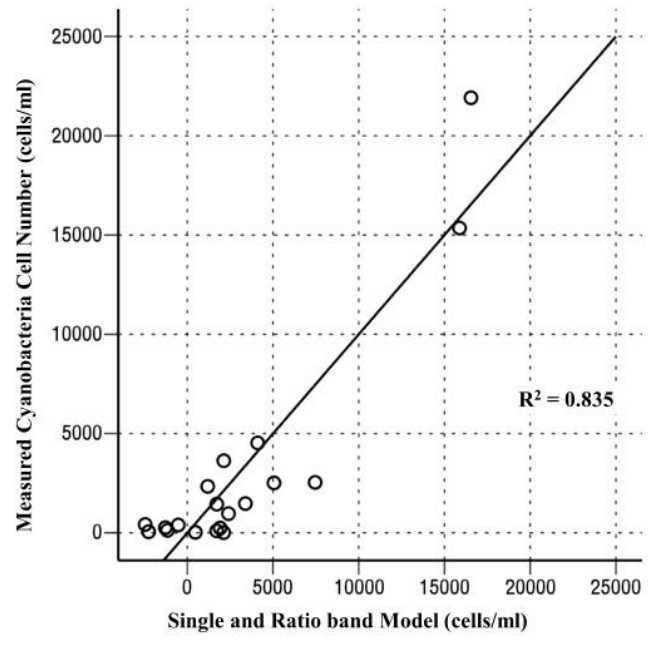

FIGURE VII. RELATIONSHIPS BETWEEN MEASURED AND PREDICTED CYANOBACTERIA CELL NUMBER AT DAECHEONG LAKE

\section{E. Distribution map of Cyanobacteria Cell Number}

Figure VII shows the distribution map of the Cyanobacteria Cell Number in September 30, 2006 at Daechung Lake. The study established the possibility of using multispectral sensors like Landsat for mapping of cyanobacteria in lake waters. Addition of other spectral band and their ratio can increase the efficiency of the present model, hence should be included as potential option for modification in further study.

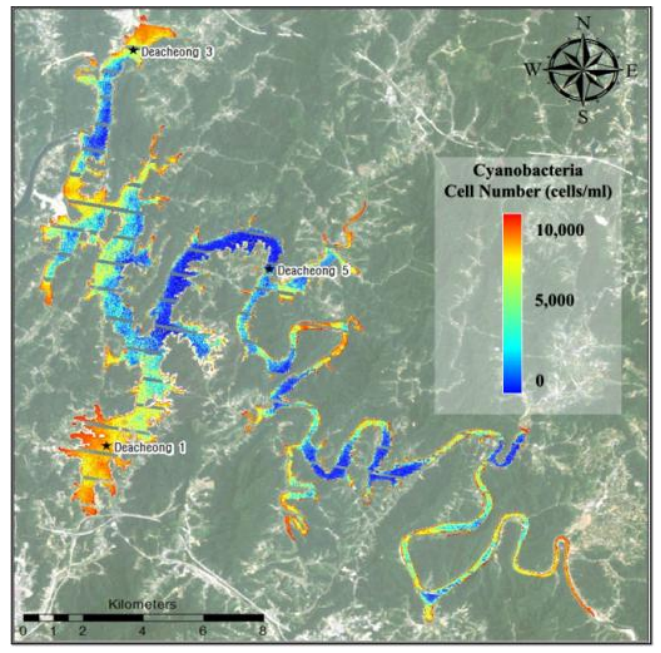

FIGURE VIII. DISTRIBUTION MAP OF CYANOBACTERIA CELL NUMBER IN SEP. 30, 2006

\section{CONCLUSIONS}

Although there is limitations still exist in current applications, the present study shows that remote sensing can play a significant role in estimating algal blooms in lakes with large geographical areas. There is no doubt that an effective monitoring and detecting system of algal blooms through remote sensing requires the coupling of powerful strategies and a comprehensive understanding of the biological mechanisms behind the formation of algal blooms in lakes. Still the method is expected to provide a valuable opportunity to investigate the 
factors that are important in determining the development and distribution of algal bloom in large water systems.

\section{REFERENCES}

[1] G. Hallegraeff, "A review of harmful algal blooms and their apparent global increase", Phycologia, Vol. 32 (2), 1993, p.80.

[2] W. Carmichael, N. Mahmood, and E. Hyde, "Natural toxins from cyanobacteria (blue-green algae)". In: S. Hall and G. Strichartz [Eds] Marine Toxins, Origin, Structure and Molecular Pharmacology, Vol. 418, American Chemical Society, Washington D.C., 1990, pp. 87-106.

[3] D. Baganz, G. Staaks, and C. Steinberg, "Impact of the cyanobacteria toxin, microcystin-LR, on the behavior of zebrafish", Danio rerio. Wat. Res., 32, 1998, pp.948-952 .

[4] G. Codd, AC. Edwards, K. Beattie, L. Lawton, D. Campell, and S. Bell, 1995 "Toxins from blue-green algae". The Pringsheim Lecture. In: W. Wiessner, E. Schnepf and R. C. Starr [Eds] Algae, Environment and Human Affairs. Biopress, Bristol, 1995, pp. 1-17. 